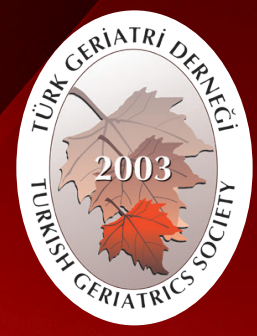

Turkish Journal of Geriatrics

DOI: 10.31086/tjgeri.2019150572

2019;22 (1):48-55

- Ayşe İlksen ÇOLPAK ${ }^{1}$ (D)

CORRESPONDANCE

Ayşe Ilksen ÇOLPAK

Hacettepe University, Faculty of Medicine,

Department of Neurology, Ankara, Turkey

Phone: 03123051806

e-mail: ilksenisikay@yahoo.com.tr

Received: $11 / 12 / 2018$

Accepted: $24 / 01 / 2019$

Hacettepe University, Faculty of Medicine, Department of Neurology, Ankara, Turkey

\title{
PROFILE OF GERIATRIC PATIENTS IN A NEURO-OPHTHALMOLOGY OUTPATIENT CLINIC
}

\section{Abstract}

Introduction: To determine the clinical profile of geriatric patients in a neuroophthalmology outpatient clinic of a tertiary center.

Materials and Method: Retrospective evaluation of medical records from the institutional database, including patients aged $\geq 65$ years who were treated by the same neuroophthalmologist, was performed.

Results: A total of 99 (52 F, 47 M) geriatric patients were analyzed. Mean age was $72.14 \pm 5.26$ years. The most frequent complaint was visual loss $(48.9 \%)$, followed by oculomotor abnormalities (38.7\%). Thirty-eight of 48 patients had permanent visual loss, whereas 10 had transient visual loss. Patients with permanent visual loss were older than those with transient visual loss [mean ages of $73.05 \pm 5.85$ and $68.5 \pm 2.84$ years, respectively $(p=0.022)$ ]. Diplopia was the primary symptom, followed by ptosis in the oculomotor group.

Conclusion: Neuro-ophthalmological diseases have many manifestations in the aging population. Physiological changes and risk factors associated with aging may lead to different complaints from young adults. This study contributed to the neuro-ophthalmological profile of Turkish geriatric patients.

Keywords: Diplopia; Vision, Ocular; Blepharoptosis; Aged

\section{NÖRO-OFTALMOLOJi POLIKLINIǴíNDEKI GERIATRI YAS GRUBUNDAKI HASTALARIN ÖZELLIKLERI}

\author{
$\ddot{O}_{z}$
}

Giriş: Üçüncü basamak bir merkezin nöro-oftalmoloji polikliniğindeki geriatri yaş grubundaki hastaların klinik özelliklerinin belirlenmesi amaçlanmıştır.

Gereç ve Yöntem: Aynı nöro-oftalmolog tarafından takip edilen 65yaş ve üzerindeki hastaların tıbbi kayıtları geriye dönük olarak incelendi.

Bulgular: Toplamda 99 ( 52 K, 47 E) geriatrik hasta analiz edildi. Ortalama yaş $72.14 \pm 5.26$ olarak saptandı. En sık görülen yakınma görme kaybı (\%48.9) iken, takiben oküler motor anormallikler (\%38.7) gelmekteydi. Kırk sekiz hastanın 38\'inde kalıcı görme kaybı varken, 10 hastada geçici görme kaybı izlendi. Kalıcı görme kaybı olan hastalar, geçici görme kaybı olanlara göre daha yaşlıydı [ortalama yaşlar sırasıyla; $73.05 \pm 5.85$ ve $68.5 \pm 2.84$ yaş, $(p=0.022)$ ]. Oküler motor grupta diplopi birincil semptom olup, ikinci sırada pitoz yer almaktaydı.

Sonuç: Nöro-oftalmolojik hastalıkların yaşlı populasyonda birçok belirtisi vardır. Yaşlanmayla ilişkili fizyolojik değişiklikler ve risk faktörleri, genç erişkinlerden farklı yakınmalara yol açabilir. Bu çalışma Türk geriatri yaş grubundaki hastaların nöro-oftalmoloji profilinin ortaya konmasına katkı sağlamıştır.

Anahtar Sözcükler: Çift görme; Görme; Pitoz; Yaşlılık 


\section{INTRODUCTION}

The elderly population has been increasing in recent decades. With aging, reduced adaptation and compromised biological functions are observed. Presbyopia is a good example of the normal loss of focusing ability with regard to near objects, which occurs with advanced age (1). Bodily systems are vulnerable to diseases; as the life span is extended, the likelihood of health problems increases (2).

Visual problems related to the nervous system constitute a group of disorders that may occur at any age and impact daily life. The most common complaints are visual loss, diplopia, and eye pain.

Moreover, the clinical profile of neuroophthalmological involvement can be different in young and geriatric patients. For instance, optic neuropathy is often associated with inflammation in young people, whereas it is associated with ischemia in the elderly (3).

Importantly, there are even more unfavorable effects of visual loss in the geriatric population such as depression, falls, and poorer quality of life (4).

Age-relatedmaculopathy, cataract, and glaucoma are the most common reasons for elderly patients to seek admission to an ophthalmology clinic (5). Pupil involving third cranial nerve palsy, anterior ischemic optic neuropathy, Horner syndrome, and diplopia are infrequent manifestations, but should not be missed by ophthalmologists and neurologists.

In this study, the clinical profile of patients $\geq 65$ years was studied to assess the common diagnoses and etiological factors encountered in the neuroophthalmology outpatient clinic of a single center.

\section{MATERIALS AND METHOD}

\section{Data collection}

Medical records of patients aged $\geq 65$ years, who were referred to the neuro-ophthalmology clinic of a tertiary medical center were reviewed. This retrospective study was approved by the ethics committee of our institution (number: GO18/678), in accordance with the Declaration of Helsinki. All the included patients were examined and followed by the same neuro-ophthalmologist, and had been treated between June 2014 and November 2014 or December 2015 and June 2018.

Demographic information, including age and sex, medical history prior to neurological disease, diabetes mellitus, hypertension, and hypercholesterolemia; and the presence of concomitant ocular diseases, such as macular degeneration, glaucoma, and diabetic retinopathy were recorded. Complete neuro-ophthalmological assessment was performed, including visual acuity (using a Snellen chart), color vision (using the Ishihara test), pupillary examination, visual fields by confrontation, and fundus examination. Imaging studies (magnetic resonance imaging, carotid and Cerebral computed tomography angiography) and electrophysiological studies (single-fiber electromyography and visual evoked potentials) were recorded.

\section{Statistical analysis}

Statistical analyses were performed with Wizard 1.9.18 for MacOS. Numerical variables are presented as the mean \pm standard deviation or median (min-max); categorical variables presented as frequencies and percentages. Categorical variables were compared using the chi-squared test; continuous variables were compared using the Mann-Whitney $U$ test. A $p$ value of less than 0.05 was considered statistically significant.

\section{RESULTS}

During the periods of June 2014 to November 2014 and December 2015 to June 2018, in almost 3 years, 129 patients aged $\geq 65$ years, who were admitted to our neuro-ophthalmology outpatient clinic, were evaluated for participation in the study. Ninety-nine of these patients had complete medical records, including history, examination, and work-up. These 99 patients had a mean age of $72.14 \pm 5.26$ years. The number of females $(n=52)$ and males $(n=47)$ 
patients was similar, and the mean age of the female patients $(72.9 \pm 5.25$ years) was similar to that of the male patients $(72.9 \pm 5.25$ years). The most frequent complaint was visual loss (48.9\%), followed by oculomotor abnormalities (38.7\%) and others (12.4\%).

Of the 48 patients $(22 \mathrm{~F}, 26 \mathrm{M})$ who presented with visual loss, 38 had permanent loss of vision and 10 had transient loss of vision. Patients with permanent visual loss (mean age, $73.05 \pm 5.85$ years) were older than those with temporary visual loss (mean age, $68.5 \pm 2.84$ years) $(p=0.02)$. Among patients aged 65 74 years, the proportion with permanent visual loss was $67.9 \%$ and the proportion with transient visual loss was $32.1 \%$; among patients aged $\geq 75$ years, the proportions with permanent and transient visual loss were $95 \%$ and $5 \%$, respectively $(p=0.022)$.

In the permanent visual loss group, the most common cause was non-arteritic ischemic optic neuropathy (NAION), which was observed in 18 of 38 patients (47.3\%). In the transient visual loss group, amaurosis fugax (AF) was the most common cause, observed in 5 of 10 patients (50\%). The diagnoses of patients with visual loss are summarized in Table 1. Among the group of patients with ischemic optic neuropathy, 3 had elevated sedimentation and C-reactive protein levels, all of whom underwent temporal artery biopsy, and 2 were diagnosed with arteritic ischemic optic neuropathy (AION).

Table 1. Characteristics of patients with visual loss.

\begin{tabular}{|c|c|}
\hline Characteristics & Value \\
\hline Mean age $\pm s d$ & $72.10 \pm 5.65$ \\
\hline Female & 22 \\
\hline Permanent visual loss & 38 (38.4\%) \\
\hline NAION & 18 (18.2\%) \\
\hline Occipital CVD & $4(4.1 \%)$ \\
\hline Cataract & $4(4.1 \%)$ \\
\hline Atypical ON & $3(3.0 \%)$ \\
\hline Retinal & $3(3.0 \%)$ \\
\hline AION & $2(2.0 \%)$ \\
\hline SMD & $2(2.0 \%)$ \\
\hline Others & $2(2.0 \%)$ \\
\hline Transient visual loss & $10(10.1 \%)$ \\
\hline$A F$ & $5(5.1 \%)$ \\
\hline Migraine & $4(4.0 \%)$ \\
\hline Unexplained & $1(1.0 \%)$ \\
\hline
\end{tabular}

NAION: Non-arteritic ischemic optic neuropathy, CVD: cerebro-vascular disorder, ON: optic neuritis, AION: anterior ischemic optic neuropathy, SMD: senil macular degeneration, AF: amaurosis fugax 
Thirty-nine patients (23 F, 16 M) exhibited oculomotor symptoms. The mean age of these patients was $72.69 \pm 4.7$ years. Female patients with oculomotor symptoms were marginally older than male patients with oculomotor symptoms (mean ages $73.91 \pm 3.9$ and $70.94 \pm 5.3$ years, respectively) $(p=0.05)$. Diplopia was the most common oculomotor symptom, observed in 29 patients who had various final diagnoses. There was no difference between the group with individuals aged 65-74 years and that with those aged $\geq 75$ years regarding the incidence of diplopia and ptosis $(p=0.07)$. Five patients were diagnosed with myasthenia gravis, based on symptoms of diplopia (1 patient) and ptosis (4 patients). MG was diagnosed on the basis of the results of single-fiber EMG; all MG patients were seropositive for acetylcholine receptor antibody. The most common cause of ptosis was age-related senile ptosis. Oculomotor abnormalities are summarized in Table 2.

Other symptoms were as follows: blepharospasm $(n=4)$, scleral hyperemia $(n=3)$, progressive supranuclear palsy $(n=1)$, periorbital ecchymosis $(n=1)$, diabetic papillopathy $(n=1)$, trigeminal sensory neuropathy $(n=1)$, and orbital mass $(n=1)$.

Table 2. Characteristics of patients with ocular motor abnormalities.

\begin{tabular}{|l|r|}
\hline Characteristics & Value \\
\hline Mean age \pm sd & $72.69 \pm 4.7$ \\
\hline Female & $23(23.2 \%)$ \\
\hline Diplopia & $29(29.3 \%)$ \\
\hline $4^{\text {th }}$ nerve palsy & $10(10.1 \%)$ \\
\hline $6^{\text {th }}$ nerve palsy & $7(7.1 \%)$ \\
\hline $3^{\text {rd }}$ nerve palsy & $5(5.1 \%)$ \\
\hline Strabismus & $3(3.0 \%)$ \\
\hline MG & $1(1.0 \%)$ \\
\hline CCF & $1(1.0 \%)$ \\
\hline Others & $2(2.0 \%)$ \\
\hline Ptosis & $10(10.1 \%)$ \\
\hline Senile & $5(5.1 \%)$ \\
\hline MG & $4(4.0 \%)$ \\
\hline Horner & $1(1.0 \%)$ \\
\hline
\end{tabular}

MG: Myathenia Gravis, CCF: carotico-cavernous fistula

\section{DISCUSSION}

A retrospective review of geriatric patients was performed in a single center neuro-ophthalmology outpatient clinic. This study demonstrated that among the geriatric population, the main cause of referral to the neuro-ophthalmology outpatient clinic was visual loss. Moreover, patients with permanent visual loss were older than those with transient visual loss. 
Visual loss occurs due to various causes, which are mostly related to ocular diseases such as maculopathy, cataract, diabetic retinopathy, glaucoma, refractive errors, and ocular trauma (5, 6). Although visual loss is primarily ocular, it may occur as a result of a systemic disease, or in relation to a neurological condition, such as the underlying factors associated with AF. In elderly patients with complaints of monocular transient visual loss, physicians should consider vascular-occlusive diseases in the differential diagnosis.

Patients with AF experience sudden transient visual loss and exhibit normal recovery after the episode. The type of visual loss primarily depends on the type of ocular vascular-occlusive disorder. Unless the visual loss occurs as a result of branch vessel occlusion, the entire visual field is affected. Most patients describe painless monocular loss of vision to appear in a manner similar to that of a shade or curtain, lasting 1-5 min; generally, it is not accompanied with positive visual phenomena, such as photopsia or scintillating scotoma (7).

The primary causes underlying the onset of AF include transient impaction of an embolus in an artery, reduction in perfusion pressure (i.e., marked drop in mean arterial pressure, or increase in intraocular pressure), or thrombus in central or branch retinal veins.

A comprehensive study of AF showed that central vein occlusion with cilioretinal artery occlusion is the most common cause of AF (37.84\%), whereas NAION is the least common cause (2.54\%) (7). Five of 10 patients with transient visual loss exhibited AF; among these 5 patients, only 1 had an ulcerated carotid plaque. The rest of the patients demonstrated microvascular ischemic disease. No reciprocal association was observed between NAION and AF symptoms in our patients. Moreover, there was no sign of retinal vessel involvement. This may have been due to the small number of patients; alternatively, because the patients had been referred from the hospital's ophthalmology outpatient clinic, AF related to retinal disease might have already been diagnosed.

Eighteen patients were diagnosed with NAION, with an episode of painless acute visual loss, optic disc edema, and altitudinal hemianopia. All of these patients demonstrated permanent visual loss, with final visual acuities below 20/100, as measured by Snellen cards. One patient underwent temporal artery biopsy due to the signs of systemic inflammation; importantly, the result was normal. Thirteen patients had at least 1 vascular risk factor for atherosclerosis. The most important concern for these patients was differentiation of NAION from AION. Both conditions show the same neuroophthalmological clinical picture, although in the presence of "red flags," giant cell arteritis-related AION should be considered. This is a medium and large-sized systemic vasculitis that is primarily observed in women and patients aged $>50$ years. It is often described as temporal arteritis due to its association with small-artery thickening under the temporal skin region. Temporal arteritis tends to involve the ophthalmic artery and its branches in the orbit (8). Recognition of temporal arteritis is essential; ION patients with a history of headache, jaw claudication, and elevated erythrocyte sedimentation rate/C-reactive protein level require immediate steroid treatment. Although steroid treatment does not reverse existing visual loss in the affected eye, it prevents further deterioration of the unaffected eye. The diagnosis is based on American College of Rheumatology giant cell arteritis criteria (9). At least 3 of the 5 criteria are required for a definitive diagnosis (Table 3 ). Histological features in biopsy are not affected by steroids even after 2 weeks of treatment, therefore no need to delay steroid treatment and wait for biopsy to be done (10). Arterial involvement is segmental, and the length of the biopsy specimen must be minimum $2 \mathrm{~cm}$. In our geriatric group, 2 patients were diagnosed with AION via confirmed biopsy; these patients experiences severe vision loss, relative to that of the NAION group, which 
was in accordance with the findings of previous reports (11).

Our NAION patients did not undergo steroid therapy or optic nerve decompression surgery. The only medical treatment in our group was low-dose acetylsalicylic acid. The Ischemic Optic Neuropathy Decompression Trial showed that optic nerve decompression surgery was not effective for NAION patients. In contrast, $42.7 \%$ of patients in the observation group who had visual acuity worse than 20/64 at presentation regained minimum 3 lines on the Snellen eye chart within 6 months (12). In our group, 10 of 18 NAION patients underwent long-term follow-up; 3 of these patients regained 2 lines in the Snellen chart, whereas the rest did not improve.

Although there is no clear relationship between medications and NAION, several medications, including phosphodiesterase type 5 inhibitors, amiodarone, nasal decongestants, and vasopressor agents have shown a potential for causing ischemic optic neuropathy (13-15). None of our patients reported these specific medications.

Patients with transient visual loss were younger $(p=0.02)$, and most frequently had been affected by AF (5 patients). The second most common cause was migraine with aura (4 patients) (Table 1). While patients with AF demonstrated atherosclerotic risk factors, patients who had migraine with aura did not. Visual auras were fully reversible, typically last $<1$ h, gradually develop and disappear, and occur as flashing lights, zig-zags, and scintillating scotomas. Typical aura without headache was previously known as acephalgic headache; a typical migraine aura that is neither accompanied with, nor followed by headache occurs in $4 \%$ of migraine patients.(16).

Migraine is known as a disease of young people; those who experience migraines typically report their first attack in the first 3 decades of life. However, Late Onset Migraine Accompaniments (LOMA) is an established subtype of typical aura without headache; it manifests after 45 years of age and is more common in elderly patients. Although LOMA can be sensorial, motor, or visual, the most common auras are visual $(16,17)$.

Only 1 migraine patient experienced visual symptoms without headache in our study group. This may have been due to the limited number of patients.

Oculomotor abnormalities were the second most common cause of referral to the neuroophthalmology outpatient clinic in our cohort; among the affected patients, diplopia was the main symptom, followed by ptosis. It is important to determine whether the diplopia is binocular or monocular. Monocular diplopia is related to the eye only and is not occur as a result of a neurological problem. All the study patients with diplopia had binocular diplopia; in 22 of 29 patients and resulted from oculomotor cranial nerve palsies (OMNP). As in previous reports, microvascular ischemia was the primary etiology observed in our OMNP patients; it manifested in 9 of 10 patients with fourth nerve palsy, 6 of 7 patients with sixth nerve palsy, and 3 of 5 patients with third nerve palsy. Microvascular oculomotor ischemia is a presumptive diagnosis based on a history of vascular risk factors, absence of neurological findings other than OMNP, and complete recovery within 3 months. It is controversial whether clinicians should observe affected patients for 3 months, or whether they should perform neuroimaging at the time of diagnosis $(18,19)$. In studies with a large number of patients, 50 years of age is accepted as a cut-off threshold; neurological imaging is not recommended for individuals older than this age (20). In our study cohort, all patients with OMNP underwent brain MRI at the time of admission; 2 patients with third nerve palsy were diagnosed with metastatic lung cancer and caroticocavernous fistula, respectively, whereas 1 patient with sixth nerve palsy demonstrated an internal carotid aneurysm. Although this study involved a small number of patients aged $>50$ years, some exhibited life-threatening diagnoses. Therefore, and because of the reduced cost and increased 
availability of MRI, physicians should consider early imaging in patients with OMNP. Additionally, MG can mimic fourth, sixth, and pupil-sparing third nerve palsies; importantly, the incidence of MG increases with the increase in age. Particularly among patients with an incomplete OMNP clinical picture, testing for MG is essential (21).

Orbital connective tissue can deteriorate in a manner similar to that of other body structures during the process of aging. Aponeurotic blepharoptosis and limited supraduction due to inferior displacement of horizontal rectus pulleys are notable examples of age-related ptosis and strabismus. Sagging eye syndrome is a relatively new term in the diplopia literature since 2009; in this syndrome, the lateral rectus muscle is inferiorly displaced due to age-related lateral rectus-superior rectus band degeneration (22). Heterophoria decompensation is another cause of diplopia; it may occur due to longstanding visual deprivation, such as cataract (23). When making these diagnoses, the primary consideration for a clinician is to first consider these diagnoses, and the second is to exclude other reasons of paralytic strabismus. In this retrospective study, none of the patients exhibited limited supraduction or sagging eye syndrome. This is the primary limitation of the study. The author of this manuscript was not familiar with sagging eye syndrome when these patients were admitted, and orbital neuroimaging was not available for some of the patients. Notably, limited supraduction can be a finding of old age; however, if it was not considered in association with a disease, it may not have been recorded.

In this study cohort, there were 4 patients with homonymous hemianopia, which resulted from occipital infarction; however, there were no patients with higher visual cortical disorders, such as achromatopsia, simultanagnosia, or prosopagnosia. These symptoms are caused by damage to the extrastriate visual cortex and other vision-related temporoparietal areas. This is another limitation of the study, in that almost all the patients were referred from an ophthalmology clinic and these symptoms may not have been recognized by the referring clinicians. Even in stroke units, such symptoms may be overlooked because of other severe neurological findings. One point to emphasize is the importance of education in neuroophthalmological examination.

To the best of my knowledge, this is the first retrospective neuro-ophthalmological evaluation of a geriatric population in Turkey. Further prospective studies with a large number of patients, as well as a comparison with young patients, may better illustrate the etiologies present in geriatric patients.

Table 3. American College of Rheumatology classification criteria for giant cell arteritis (9). At least 3 of 5 criteria must be met.

\begin{tabular}{|l|l|}
\hline i & Age at disease onset $>50$ years: development of symptoms or findings beginning at the age of $>50$ years \\
\hline ii & New headache: new onset of or new type of localized pain in the head \\
\hline iii & $\begin{array}{l}\text { Temporal artery abnormality: temporal artery tenderness to palpation or decreased pulsation, unrelated to } \\
\text { arteriosclerosis of cervical arteries }\end{array}$ \\
\hline iv & Elevated erythrocyte sedimentation rate: $55 \mathrm{~mm} / \mathrm{hour}$ by the Westergren method \\
\hline v & $\begin{array}{l}\text { Abnormal artery biopsy: biopsy specimen with artery showing vasculitis characterized by a predominance of } \\
\text { mononuclear cell infiltration or granulomatous inflammation, usually with multinucleated giant cells }\end{array}$ \\
\hline
\end{tabular}




\section{REFERENCES}

1. Glasser A, Campbell MC. Presbyopia and the optical changes in the human crystalline lens with age. Vision Res 1998;38(2):209-29. (PMID:9536350).

2. Boss GR, Seegmiller JE. Age-related physiological changes and their clinical significance. West J Med. 1981;135(6):434-40. (PMID:7336713).

3. Costello F. Inflammatory optic neuropathies. Continuum (Minneap Minn) 2014;20 (4 Neuroophthalmology):816-37. (PMID:25099096).

4. Crews JE, Chou CF, Zhang X, Zack MM, Saaddine JB. Health-related quality of life among people aged >/=65 years with self-reported visual impairment: findings from the 2006-2010 behavioral risk factor surveillance system. Ophthalmic Epidemiol 2014;21(5):287-96. (PMID:24955821).

5. Evans JR, Fletcher AE, Wormald RP, Assessment MRCTo, Management of Older People in the C. Causes of visual impairment in people aged 75 years and older in Britain: an add-on study to the MRC Trial of Assessment and Management of Older People in the Community. Br J Ophthalmol 2004;88(3):365-70. (PMID:14977771).

6. Yakin M, Yalniz-Akkaya Z, Sevim-Yakin S, Balta O, Ornek F. Ophthalmologic evaluation in geriatric patients: Assessment of consistency between patients' complaints and ocular diagnoses. Arch Gerontol Geriatr 2017;68:90-6. (PMID:27710877).

7. Hayreh SS, Zimmerman MB. Amaurosis fugax in ocular vascular occlusive disorders: prevalence and pathogeneses. Retina 2014;34(1):115-22. (PMID:23632956).

8. Vodopivecl, Rizzo JF, 3rd. Ophthalmic manifestations of giant cell arteritis. Rheumatology (Oxford) 2018;57(suppl_2):ii63-ii72. (PMID:29986083).

9. Hunder GG, Bloch DA, Michel BA, et al. The American College of Rheumatology 1990 criteria for the classification of giant cell arteritis. Arthritis Rheum 1990;33(8):1122-8. (PMID:2202311).

10. Achkar AA, Lie JT, Hunder GG, O'Fallon WM, Gabriel SE. How does previous corticosteroid treatment affect the biopsy findings in giant cell (temporal) arteritis? Ann Intern Med 1994;120(12):987-92. (PMID:8185147).

11. Liu GT, Glaser JS, Schatz NJ, Smith JL. Visual morbidity in giant cell arteritis. Clinical characteristics and prognosis for vision. Ophthalmology 1994;101(11):1779-85. (PMID:7800356).
12. Optic nerve decompression surgery for nonarteritic anterior ischemic optic neuropathy (NAION) is not effective and may be harmful. The Ischemic Optic Neuropathy Decompression Trial Research Group. JAMA 1995;273(8):625-32. (PMID:7844872).

13. Murphy MA, Murphy JF. Amiodarone and optic neuropathy: the heart of the matter. J Neuroophthalmol 2005;25(3):232-6. (PMID:16148635).

14. Campbell UB, Walker AM, Gaffney $M$, et al. Acute nonarteritic anterior ischemic optic neuropathy and exposure to phosphodiesterase type 5 inhibitors. J Sex Med 2015;12(1):139-51. (PMID:25358826).

15. Biousse $V$, Newman NJ. Ischemic Optic Neuropathies. N Engl J Med 2015;372(25):2428-36. (PMID:26083207).

16. Shah DR, Dilwali S, Friedman DI. Correction to: Migraine Aura Without Headache. Curr Pain Headache Rep 2018;22(12):85. (PMID:30343336).

17. Fisher CM. Late-life migraine accompaniments as a cause of unexplained transient ischemic attacks. Can J Neurol Sci 1980;7(1):9-17. (PMID:7388704).

18. Chou KL, Galetta SL, Liu GT, et al. Acute ocular motor mononeuropathies: prospective study of the roles of neuroimaging and clinical assessment. J Neurol Sci 2004;219(1-2):35-9. (PMID:15050435).

19. Tamhankar MA, Biousse V, Ying GS, et al. Isolated third, fourth, and sixth cranial nerve palsies from presumed microvascular versus other causes: a prospective study. Ophthalmology www2013;120(11):2264-9. (PMID:23747163).

20. Richards BW, Jones FR, Jr., Younge BR. Causes and prognosis in 4,278 cases of paralysis of the oculomotor, trochlear, and abducens cranial nerves. Am J Ophthalmol 1992;113(5):489-96. (PMID:1575221).

21. Vincent A, Clover L, Buckley C, et al. Evidence of underdiagnosis of myasthenia gravis in older people. J Neurol Neurosurg Psychiatry 2003;74(8):1105-8. (PMID:12876244).

22. Chaudhuri Z, Demer JL. Sagging eye syndrome: connective tissue involution as a cause of horizontal and vertical strabismus in older patients. JAMA Ophthalmol 2013;131(5):619-25. (PMID:23471194).

23. Cioplean D, Nitescu Raluca L. Age related strabismus. Rom J Ophthalmol 2016;60(2):54-8. (PMID:29450323). 